\title{
PENGARUH BEBERAPA VARIABEL TERHADAP PEMILIHAN METODE PENILAIAN PERSEDIAAN PADA PERUSAHAAN MANUFAKTUR
}

\author{
Herlin Tundjung Setijaningsih $^{1}$; Cecilia Dewi Pratiwi ${ }^{2}$ \\ ${ }^{1}$ Fakultas Ekonomi Universitas Tarumanagara dan Associate \\ Jln. S. Parman No.1, Jakarta Barat 11440 \\ ${ }^{2}$ Jurusan Akuntansi, Fakultas Ekonomi, Universitas Bina Nusantara \\ herlin_tundjung@yahoo.com
}

\begin{abstract}
This study aims to provide empirical evidence whether the size of the company, inventory intensity, variability cost of sales, and accounting earnings variability influence the choice of inventory valuation methods. The object of this research was manufacturing companies listed in Indonesia Stock Exchange in the period 2005-2009. Thirty nine samples in this study were taken by several criteria. Statistical analysis tool used in this research was logistic regression with a significance level of 5\%. From the test result, it was obtained that either partially or simultaneously, company size, intensity of inventory, price variability of goods sold, and income variability have a significance level above 5\%. This shows that these variables did not significantly influence the selection method of inventory valuation.
\end{abstract}

Keywords: company size, inventory intensity, variability cost of sales, accounting earning variability

\begin{abstract}
ABSTRAK
Penelitian ini bertujuan untuk memberikan bukti empiris apakah ukuran perusahaan, intensitas persediaan, variabilitas biaya penjualan, dan akuntansi yang mempengaruhi penghasilan variabilitas pilihan metode penilaian persediaan. Objek penelitian ini adalah perusahaan manufaktur yang terdaftar di Bursa Efek Indonesia pada periode 2005-2009. Tigapuluh sembilan sampel dalam penelitian ini diambil oleh beberapa kriteria. Alat analisis statistik yang digunakan dalam penelitian ini adalah regresi logistik dengan tingkat signifikansi 5\%. Tes menggunakan SPSS for Windows versi 17.00. Dari hasil pengujian, diperoleh bahwa baik secara parsial maupun simultan, ukuran perusahaan, intensitas persediaan, variabilitas harga pokok penjualan, dan variabilitas pendapatan memiliki tingkat signifikansi di atas 5\%. Hal ini menunjukkan bahwa variabelvariabel ini tidak signifikan mempengaruhi pemilihan metode penilaian persediaan.
\end{abstract}

Kata kunci: ukuran perusahaan, intensitas persediaan, variabilitas harga pokok penjualan, variabilitas laba akuntansi 


\section{PENDAHULUAN}

Laporan keuangan merupakan suatu ringkasan atas transaksi-transaksi yang terjadi pada perusahaan. Laporan ini sangat berguna dari para pemakai laporan keuangan seperti investor karena dapat dijadikan sebagai acuan dalam menentukan kebijakan investasi yang akan diambil.

Dalam menyusun laporan keuangan, perusahaan harus dapat menerapkan sistem dan prosedur akuntansi yang mendukung kegiatan operasional bisnisnya. Penerapan sistem dan prosedur yang kurang tepat akan berpengaruh terhadap posisi keuangan dan hasil usaha perusahaan. Penyusunan laporan keuangan juga harus mengacu pada Pernyataan Standar Akuntansi Keuangan (PSAK). PSAK merupakan kerangka teoritis perusahaan dalam menentukan kebijakan akuntansi yang akan digunakan. Laporan keuangan yang mengacu pada PSAK akan menghasilkan laporan yang baik, akurat, dan tidak menyesatkan bagi pengguna laporan keuangan. Pada PSAK, terdapat aturan-aturan mengenai pengukuran, pengakuan, dan metode-metode penilaian dari akun-akun yang ada pada laporan keuangan. Salah satu metode penilaian yang diatur oleh PSAK adalah metode penilaian persediaan. Penerapan atas persediaan akan berpengaruh pada laporan laba rugi dan neraca.

Secara umum, terdapat 3 metode penilaian persediaan, yaitu First In First Out (FIFO), Last In First Out (LIFO), dan average (rata-rata). Pemilihan metode penilaian persediaan untuk perusahaan di Indonesia mengacu pada Pernyataan Standar Akuntansi Keuangan (PSAK) No. 14 (revisi 2008), yang memberikan kebebasan untuk menggunakan salah satu alternatif metode persediaan. Namun, PSAK No. 14 mengindikasikan bahwa hanya 2 metode persediaan, yaitu FIFO dan metode rata-rata yang dapat dipilih. Begitu juga dengan Undang-Undang No. 7 tahun 1983 jo Undang-Undang No. 10 tahun 1994 tentang Perpajakan yang hanya memperbolehkan penggunaan metode FIFO atau metode ratarata.

Perbedaan antara metode FIFO dan metode rata-rata tidak terlalu mencolok. Tetapi, dalam kondisi inflasi terjadi perbedaan yang cukup besar dari penggunaan kedua metode. Pada kondisi ini, jika perusahaan menggunakan metode FIFO, akan menghasilkan laba bersih yang tinggi karena semua harga meningkat. Hal ini bisa terjadi karena nilai persediaan akhir menjadi tinggi, sementara harga pokok penjualan rendah karena menggunakan harga sebelumnya. Sebaliknya, pada kondisi yang sama, apabila menggunakan metode Last in First Out (LIFO), maka nilai persediaan akhirnya akan menjadi rendah dan harga pokoknya akan meningkat karena menggunakan harga saat ini sehingga laba bersih perusahaan menjadi rendah. Apabila perusahaan menggunakan metode rata-rata, maka akan menghasilkan laba yang berada di antara metode FIFO dan LIFO.

Walaupun metode penilaian persediaan FIFO dan rata-rata tidak kontradiktif, namun tetap menggambarkan karakteristik increasing dan decreasing income. Decreasing income digambarkan oleh metode rata-rata sedangkan increasing income digambarkan oleh metode FIFO. Namun, demikian karena dalam rentang tahun 2005-2009 telah terjadi krisis Amerika Serikat yang berpengaruh terhadap kenaikan inflasi di Indonesia, maka metode FIFO dan metode rata-rata akan menimbulkan perbedaan income yang besar.

Berkaitan dengan pemilihan metode penilaian persediaan, Niehaus (1989) menyatakan bahwa terdapat konflik kepentingan antara manajer dan pemilik perusahaan. Konflik ini timbul karena adanya perbedaan hasil ekonomi yang diharapkan. Manajemen akan memilih metode yang meningkatkan value perusahaan, yaitu metode yang menghasilkan laba yang besar yang mencerminkan keinginan investor, dengan harapan pihak manajemen akan memperoleh bonus yang besar pula. Namun kondisi tersebut tidak diharapkan oleh pemilik karena pemilik mempertimbangkan minimalisasi biaya pajak. 
Penelitian di Indonesia yang terkait dengan persediaan di antaranya adalah yang dilakukan oleh Mukhlasin (2002) terhadap perusahaan manufaktur selama periode 1995-1999, dengan kesimpulan bahwa faktor-faktor seperti ukuran perusahaan, intensitas persediaan, variabilitas harga pokok penjualan, dan intensitas modal berpengaruh secara signifikan terhadap pemilihan metode akuntansi persediaan, sedangkan variabilitas persediaan dan variabilitas laba akuntansi tidak berpengaruh terhadap pemilihan metode akuntansi persediaan.

Penelitian tersebut direplikasi oleh Anton (2010) dengan responden yang sama, yaitu perusahaan manufaktur pada periode 2005-2008. Adapun pada penelitian Anton disimpulkan bahwa variabilitas persediaan, variabilitas laba akuntansi, dan ukuran perusahaan tidak berpengaruh terhadap pemilihan metode akuntansi persediaan. Hal ini berbeda dengan hasil yang telah diperoleh pada penelitian Mukhlasin.

Penelitian ini akan mereplikasi penelitian Anton dengan menambahkan satu variabel, yaitu variabilitas harga pokok penjualan yang berlawanan dengan variabilitas persediaan, yang sebelumnya telah diuji oleh Mukhlasin dengan memperpanjang periode penelitian, yaitu untuk tahun 2009.

Penelitian ini dilakukan untuk mengetahui bagaimana pengaruh ukuran perusahaan, intensitas persediaan, variabilitas harga pokok penjualan, dan variabilitas laba akuntansi terhadap pemilihan metode penilaian persediaan pada perusahaan manufaktur yang terdaftar di BEI. Untuk itu akan dilakukan pengujian untuk mengetahui apakah baik secara parsial maupun simultan ukuran perusahaan, intensitas persediaan, variabilitas harga pokok penjualan, dan variabilitas laba akuntansi berpengaruh dalam pemilihan metode penilaian persediaan pada perusahaan manufaktur yang terdaftar di BEI pada periode 2005-2009.

Penelitian ini bertujuan untuk mendapatkan bukti empirik mengenai pengaruh, baik secara parsial maupun simultan ukuran perusahaan, intensitas persediaan, variabilitas harga pokok penjualan, dan variabilitas laba akuntansi terhadap pemilihan metode penilaian persediaan pada perusahaan manufaktur yang terdaftar di BEI pada periode 2005-2009.

Hasil penelitian ini diharapkan dapat memberikan bukti empirik untuk mengkonfirmasi hasil penelitian Mukhlaisin (2002) dan Anton (2010). Praktisi, khususnya investor, diharapkan dapat memperoleh masukan mengenai pengaruh, baik secara parsial maupun simultan ukuran perusahaan, intensitas persediaan, variabilitas harga pokok penjualan, dan variabilitas laba akuntansi terhadap pemilihan metode penilaian persediaan pada perusahaan manufaktur yang terdaftar di BEI pada periode 2005-2009, ketika akan berinvestasi serta manajemen perusahaan diharapkan dapat memperoleh bahan pertimbangan dalam memilih metode penilaian yang dapat memberikan keuntungan bagi perusahaan.

Pemilihan metode penilaian persediaan di Indonesia mengacu pada Pernyataan Standar Akuntansi Keuangan (PSAK) No. 14 (revisi 2008) yang memberikan kebebasan bagi perusahaan untuk menggunakan salah satu alternatif metode persediaan. Menurut PSAK No. 14, terdapat 2 metode persediaan, yaitu metode FIFO dan metode rata-rata yang dapat dipilih. Begitu pula dengan Undang-Undang No. 7 tahun 1983 jo Undang-Undang No. 10 tahun 1994 tentang Perpajakan yang hanya memperbolehkan penggunaan metode FIFO atau metode rata-rata.

Kieso, Weygandt, dan Warfield (2007) berpendapat bahwa metode FIFO mengasumsikan bahwa barang-barang yang digunakan (dikeluarkan) sesuai dengan urutan pembeliannya. Dengan kata lain, metode ini mengasumsikan bahwa barang pertama dibeli adalah barang pertama digunakan (dalam perusahaan manufaktur) atau dijual (dalam perusahaan dagang). Oleh karena itu, persediaan yang tersisa merupakan barang yang dibeli paling akhir. 
Keunggulan FIFO adalah mendekatkan persediaan akhir dengan biaya berjalan. Oleh karena barang pertama yang dibeli adalah barang yang akan pertama keluar, maka nilai persediaaan akhir akan terdiri dari persediaan akhir, terutama jika laju perputaran persediaan cepat. Jika tidak terjadi perubahan harga, pendekatan ini umumnya menghasilkan nilai persediaan akhir di neraca yang mendekati biaya pengganti (replacement cost) sejak pembelian barang paling terakhir. Kelemahan dari FIFO adalah bahwa biaya berjalan tidak ditandingkan dengan pendapatan berjalan pada laporan laba rugi. Biaya pembelian awal dibebankan ke pendapatan paling akhir, yang bisa mengarah pada distorsi laba kotor dan laba bersih.

Sementara itu, Baridwan (2000) menyebutkan bahwa barang-barang yang dipakai atau dijual akan dibebani harga pokok rata-rata. Perhitungan harga pokok rata-rata dilakukan dengan cara membagi jumlah harga perolehan dengan kuantitasnya. Abdullah dan Djalil (2004) juga menyimpulkan metode rata-rata didasarkan pada asumsi bahwa barang terjual harus dibebankan pada suatu biaya rata-rata seperti rata-rata yang dipengaruhi atau ditimbang oleh unit yang diperoleh pada tingkat harga tertentu. Cara ini mengurangi dampak dari fluktuasi harga.

Pemilihan atas metode akuntansi persediaan didasarkan pada alasan-alasan tertentu. Tuanakotta (2000) menyatakan bahwa ada satu alasan yang membenarkan penggunaan metode penilaian yang berbeda untuk inventory, yakni setiap metode mencerminkan keadaan ekonomi yang berbeda-beda. Pertimbangan ekonomi utama dalam memilih metode akuntansi adalah perpajakan. Pertimbangan lain dalam memilih metode akuntansi adalah untuk meningkatkan value bagi perusahaan melalui peningkatan kemakmuran pemegang saham.

Ukuran perusahaan merupakan variabel volatilitas operasional dan inventory controlability yang seharusnya dalam skala ekonomis, besarnya perusahaan menunjukkan pencapaian operasi lancar dan pengendalian persediaan (Lee dan Hsieh, 1985). Watts dan Zimmerman (1986) menyatakan jika perusahaan sensitif terhadap variasi ukuran perusahaan. Perusahaan yang lebih besar akan menyukai prosedur (metode) akuntansi yang dapat menunda pelaporan earning. Perusahaan besar relatif lebih sensitif dibandingkan dengan perusahaan kecil. Pada masa perubahan harga, metode FIFO akan menghasilkan laba yang lebih besar jika harus dibayar perusahaan. Laba yang lebih kecil (dengan menggunakan metode rata-rata) menandakan bahwa metode transfer kekayaan keluar perusahaan (biaya pajak) menjadi lebih kecil jika dibandingkan dengan laba yang lebih besar (dengan menggunakan metode FIFO). Inilah yang menyebabkan manajemen memilih metode rata-rata.

Perputaran persediaan dan hari perputaran persediaan dipengaruhi oleh metode persediaan. Oleh karena metode LIFO menghasilkan nilai persediaan akhir pada neraca yang lebih rendah dan harga pokok penjualan yang lebih tinggi dibandingkan metode FIFO, maka perusahaan dengan metode LIFO mempunyai indikasi inventory turn over yang lebih tinggi dan hari perputaran persediaan yang lebih rendah dibandingkan jika perusahaan menggunakan metode FIFO. Asumsinya bahwa perputaran persediaan yang tinggi mengindikasikan efisiensi manajemen persediaan (Lie dan Hsieh, 1985).

Harga pokok penjualan merupakan konsep yang telah digunakan secara luas dalam menentukan net income (Tuanakotta, 2000). Kondisi inflasi (perubahan harga), selain berpengaruh terhadap nilai persediaan akhir juga berpengaruh terhadap harga pokok penjualan (Kieso, 1992). Metode akuntansi FIFO pada kondisi inflasi akan menghasilkan harga pokok penjualan yang lebih kecil dibanding dengan metode LIFO. Hal ini disebabkan penilaian/pengakuan harga pokok penjualan berupa harga-harga awal untuk FIFO dan harga-harga akhir untuk LIFO. Identifikasi variabilitas harga pokok penjualan dalam menentukan metode akuntansi persediaan yang berbeda (FIFO atau rata-rata) disebabkan karena metode yang berbeda tersebut akan menghasilkan harga pokok penjualan yang berbeda pula.

Volatilitas operasional tergantung atas dasar output, teknologi produksi, dan lingkungan ekonomi umum (Lee dan Hsieh, 1985). Variabilitas laba akuntansi dipengaruhi oleh faktor internal 
perusahaan maupun eksternal perusahaan. Secara internal, variabilitas ini dibentuk oleh kebijakan perusahaan, baik yang berkaitan dengan teknik operasional perusahaan maupun kebijakan akuntansi perusahaan. Adapun secara eksternal, kondisi ekonomi, baik berupa inflasi maupun kebijakan pemerintah juga berdampak terhadap variabilitas laba akuntansi. Ronen dan Sadan (dalam Wolk dan Tearney, 1997) memberi penjelasan alternatif bahwa smooting income memfasilitasi manajer-manajer untuk memprediksi secara lebih baik aliran kas masa depan yang didasarkan pada nilai perusahaan.

Metode rata-rata akan menghasilkan laba akuntansi yang cenderung lebih stabil dan lebih kecil dibandingkan dengan metode FIFO karena metode rata-rata menggabungkan seluruh price inflow, sedangkan pada metode FIFO jika terjadi perubahan harga akan menghasilkan laba dengan variabilitas yang tinggi.

\section{METODE PENELITIAN}

Variabel bebas (independent variable) dalam penelitian ini adalah ukuran perusahaan, intensitas persediaan, variabilitas harga pokok penjualan, dan variabilitas laba akuntansi. Variabel terikat (dependent variable) dalam penelitian ini adalah pemilihan metode penilaian persediaan. Berdasarkan variabel-variabel tersebut, maka model penelitian dapat digambarkan sebagai berikut (Gambar 1).

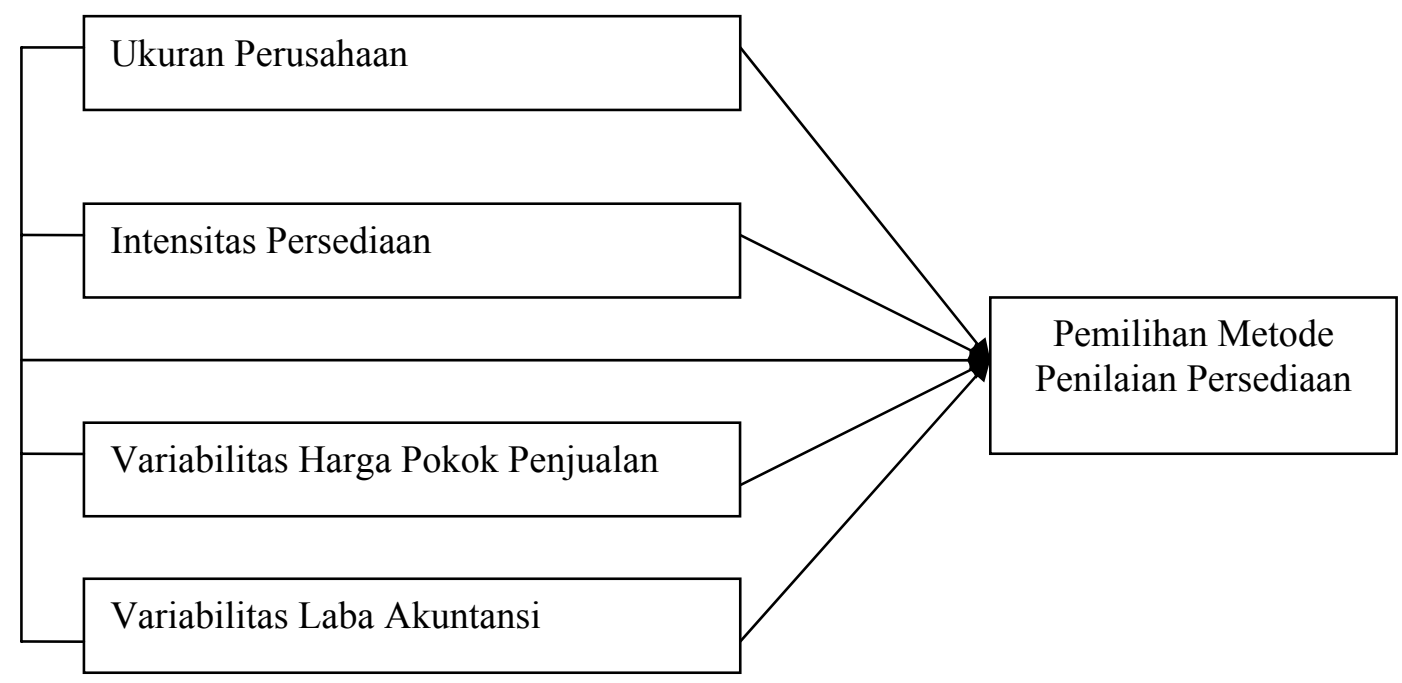

Gambar 1 Model Penelitian

Ukuran perusahaan ada 2, yaitu ukuran besar dan kecil. Perusahaan besar transaksinya lebih banyak dibandingkan dengan perusahaan yang skalanya lebih kecil. Ukuran perusahaan memiliki kaitan penting dengan pemilihan metode penilaian persediaan. Pengawasan dari pemerintah terhadap kegiatan perusahaan akan membuat perusahaan besar berhati-hati dalam bertindak. Apabila perusahaan melaporkan laba yang besar, maka perusahaan dapat dicurigai melakukan monopoli sehingga perusahaan akan memilih metode penilaian persediaan yang akan mengurangi laba yang dilaporkan. Kecenderungan metode persediaan yang akan digunakan perusahaan besar adalah metode rata-rata yang bisa menurunkan laba. Penggunaan metode rata-rata, selain bisa menghindari biaya 
politik (political cost), juga memperoleh penghematan pajak (tax saving). Sedangkan perusahaan kecil, untuk mendapatkan dana dari bank atau lembaga keuangan lainnya, membutuhkan laba yang tinggi agar dianggap mempunyai kinerja yang bagus. Salah satu cara adalah dengan menaikkan laba dengan kecenderungan menggunakan metode persediaan FIFO. Oleh karena itu, ukuran perusahaan amat berpengaruh terhadap pemilihan metode persediaan.

Berdasarkan uraian yang dilakukan di atas, maka dapat dirumuskan hipotesis pertama yaitu: $\mathrm{Ha}_{1}$ : Ukuran perusahaan berpengaruh terhadap pemilihan metode penilaian persediaan pada perusahaan manufaktur yang terdaftar di BEI tahun 2005-2009.

Intensitas persediaan atau rasio perputaran persediaan menyediakan informasi, apakah tingkat persediaan cocok dengan volume penjualan. Suatu perusahaan mempunyai rasio perputaran persediaan yang lebih rendah dibanding rasio rata-rata industrinya. Hal ini menunjukkan adanya persediaan yang sudah usang atau persediaan yang terlalu tinggi. Sebaliknya, rasio perputaran persediaan yang lebih cepat dibanding rata-rata memberi indikasi tingkat persediaan tidak cukup. Rasio ini dapat berbeda secara signifikan, tergantung apakah perusahaan menggunakan LIFO, FIFO atau rata-rata. Perputaran persediaan dan hari perputaran persediaan dipengaruhi oleh metode penilaian persediaan. Oleh karena metode rata-rata menghasilkan nilai persediaan akhir pada neraca lebih rendah dan harga pokok penjualan yang lebih tinggi, maka metode rata-rata mengindikasikan adanya inventory turn over yang tinggi. Sedangkan metode FIFO menghasilkan harga pokok penjualan yang rendah dan persediaan akhir yang tinggi sehingga menghasilkan inventory turn over yang rendah. Perputaran persediaan yang tinggi mengindikasikan efisiensi manajemen persediaan sehingga perusahaan lebih menyukai metode rata-rata. Jadi, dapat disimpulkan bahwa dalam memilih metode penilaian persediaan yang akan digunakan, perusahaan mempertimbangkan faktor ini.

Berdasarkan uraian yang dilakukan di atas, maka dapat dirumuskan hipotesis ketiga yaitu: $\mathrm{Ha}_{2}$ : Intensitas persediaan berpengaruh terhadap pemilihan metode penilaian persediaan pada perusahaan manufaktur yang terdaftar di BEI tahun 2005-2009.

Laporan laba rugi, selain melaporkan laba, juga melaporkan harga pokok penjualan. Harga pokok penjualan merupakan konsep yang telah digunakan secara luas dalam menentukan laba. Kondisi inflasi, selain berpengaruh terhadap nilai persediaan akhir, juga berpengaruh terhadap harga pokok penjualan. Metode FIFO pada saat inflasi akan menghasilkan harga pokok penjualan yang lebih rendah dibandingkan dengan LIFO. Hal ini disebabkan penilaian harga pokok penjualan berupa harga awal untuk FIFO dan harga akhir untuk LIFO. Semakin rendah harga yang dicatat, maka laba yang dihasilkan akan semakin tinggi. Dengan laba yang tinggi, akan menarik para investor untuk berinvestasi. Oleh karena itu, perusahaan akan memilih metode yang menghasilkan laba yang besar untuk dapat meyakinkan para investor.

Berdasarkan uraian yang dilakukan di atas, maka dapat dirumuskan hipotesis kedua yaitu: $\mathrm{Ha}_{3}$ : Variabilitas harga pokok penjualan berpengaruh terhadap pemilihan metode penilaian persediaan pada perusahaan manufaktur yang terdaftar di BEI tahun 2005-2009.

Laporan laba rugi adalah salah satu bagian dari laporan keuangan. Salah satu unsur yang dilaporkan dalam laporan ini adalah laba. Laba adalah besarnya total keuntungan yang diperoleh perusahaan dan hal ini menunjukkan kemampuan serta kinerja perusahaan pada tahun tertentu. Laba yang tinggi mengidentifikasikan harga saham perusahaan yang tinggi sehingga memotivasi investor menanamkan sahamnya di perusahaan sedangkan laba yang terendah menunjukkan harga saham yang rendah dan kurang mendorong investor menanamkan modalnya. Laba yang dihasilkan juga dipengaruhi oleh perusahaan. Jadi, perusahaan akan memilih metode persediaan yang akan menaikan laba agar laba yang terlampir di laporan keuangan cukup besar dan meyakinkan investor. 
Berdasarkan uraian yang dilakukan di atas, maka dapat dirumuskan hipotesis keempat yaitu: $\mathrm{Ha}_{4}$ : Variabilitas laba akuntansi berpengaruh terhadap pemilihan metode penilaian persediaan pada perusahaan manufaktur yang terdaftar di BEI tahun 2005-2009.

Faktor-faktor seperti ukuran perusahaan, intensitas persediaan, variabilitas harga pokok penjualan, dan variabilitas laba akuntansi secara bersama-sama memiliki hubungan yang kuat yang mendorong perusahaan dalam memilih metode akuntansinya. Perusahaan besar memiliki intensitas persediaan yang tinggi, dan menghasilkan nilai harga pokok penjualan yang lebih tinggi sehingga laba yang dihasilkan perusahaan menjadi lebih rendah. Besar kecilnya laba yang diperoleh tergantung dari metode penilaian persediaan yang akan digunakan oleh perusahaan.

Berdasarkan uraian yang dilakukan di atas, maka dapat dirumuskan hipotesis kelima, yaitu:

$\mathrm{Ha}_{5}$ : Ukuran perusahaan, intensitas persediaan, variabilitas harga pokok penjualan, dan variabilitas laba akuntansi berpengaruh terhadap pemilihan metode penilaian persediaan pada perusahaan manufaktur yang terdaftar di BEI tahun 2005-2009.

\section{Pemilihan Sampel}

Sampel penelitian adalah perusahaan manufaktur yang terdaftar di Bursa Efek Indonesia (BEI) pada periode 2005-2009. Pemilihan sampel ditentukan dengan cara pemilihan sampel tak acak purposive (judgemental), di mana pengambilan data disesuaikan dengan criteria-kriteria yang telah ditentukan sebelumnya (tujuannya). Kriteria yang digunakan untuk memilih sampel dalam penelitian ini adalah sebagai berikut (1) Perusahaan manufaktur yang terdaftar di BEI dan telah mempublikasikan laporan keuangan dari tahun 2005-2009; (2) Perusahaan hanya menerapkan salah satu dari metode penilaian persediaan, yaitu metode penilaian persediaan FIFO atau rata-rata untuk seluruh persediaannya selama tahun 2005-2009; (3) Perusahaan tidak melakukan perubahan metode penilaian persediaan selama tahun pengamatan, yaitu dari metode FIFO menjadi metode rata-rata ataupun sebaliknya selama tahun 2005-2009; (4) Perusahaan tidak mengalami delisting selama tahun pengamatan; dan (5) Perusahaan tidak mengalami kerugian selama 3 tahun berturut-turut.

\section{Teknik Analisis Data}

Pengolahan data dalam penelitian ini menggunakan program SPSS for windows 17.0 untuk menguji serta mengetahui pengaruh variabel bebas terhadap variabel terikat. Teknik analisis data yang digunakan dalam penelitian ini adalah dengan menggunakan analisis statistik deskriptif.

Analisis statistik deskriptif pada penelitian ini bertujuan untuk menghitung besarnya mean, minimum, maksimum, dan standar deviasi. Mean adalah rata-rata hitung untuk mengetahui rata-rata tiap rasio keuangan yang diuji pada penelitian ini. Minimum untuk mengetahui berapa nilai rasio keuangan yang paling kecil untuk tiap jenis rasio keuangan. Maksimum untuk mengetahui berapa nilai rasio keuangan yang paling besar untuk tiap jenis rasio keuangan. Standar deviasi untuk mengetahui berapa besar penyimpangan dari tiap variabel independen.

Tujuan menghitung mean, minimum, maksimum, dan standar deviasi dari masing-masing variabel ukuran perusahaan, intensitas persediaan, variabilitas harga pokok penjualan, dan variabilitas laba akuntansi adalah untuk memberikan gambaran adanya perbedaan dari hasil yang didapatkan antara perusahaan yang menerapkan metode FIFO dan average.

\section{Pengujian Hipotesis}

Uji statistik dalam penelitian ini menggunakan regresi logistik (logistic regression). Tujuan dari penggunaan regresi logistik ganda adalah untuk memprediksi besar variabel tergantung yang 
berupa variabel binary dengan menggunakan data variabel bebasnya yang sudah diketahui besarnya. Variabel binary (dummy) adalah data jenis nominal dengan 2 kriteria saja, yaitu seperti 1 = baik, $0=$ buruk, dan lain-lain. Dalam penelitian ini, variabel dummy dilambangkan 1 dan 0 , yaitu 0 berarti perusahaan menggunakan metode FIFO dan 1 melambangkan perusahaan menggunakan metode average.

Metode yang digunakan dalam regresi logistik dalam penelitian ini adalah metode ENTER dengan tingkat signifikansi sebesar 5\%. Berikut ini adalah formulanya:

$$
\mathrm{Ln} \frac{\mathrm{MPP}}{1-\mathrm{MPP}}=\beta+\beta_{1} \mathrm{UP}+\beta_{2} \mathrm{IP}+\beta_{3} \mathrm{VH}+\beta_{4} \mathrm{VL}+\mathrm{e}
$$

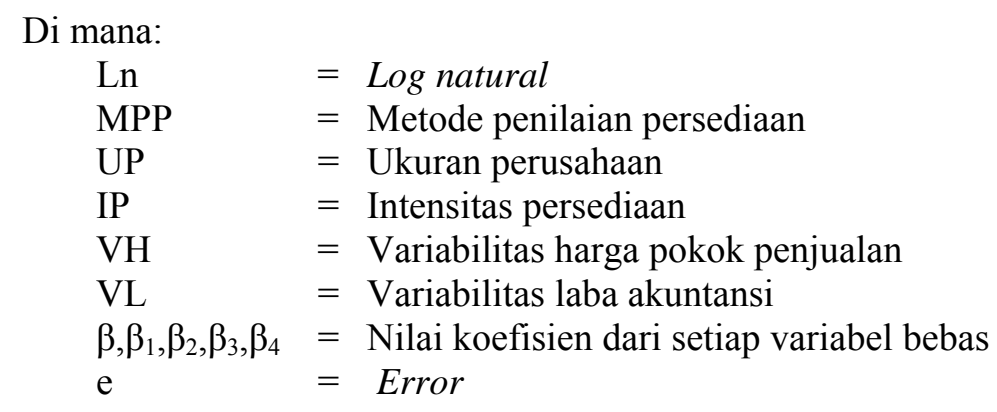

\section{HASIL DAN PEMBAHASAN}

\section{Analisis Hasil Pengumpulan Data}

Data yang diperoleh dan dipergunakan dalam penelitian ini adalah data sekunder, yaitu data dalam bentuk yang sudah jadi, sudah diolah, dan dikumpulkan oleh pihak lain. Data sekunder dalam penelitian ini berupa laporan keuangan tahunan perusahaan manufaktur yang listing di Bursa Efek Indonesia (BEI) pada periode 2005-2009.

Populasi yang menjadi objek penelitian ini adalah perusahaan manufaktur yang terdaftar di BEI, dengan mengacu pada perusahaan-perusahaan manufaktur yang termuat dalam Indonesian Capital Market Directory tahun 2004. Sampel sebanyak 39 perusahaan yang memenuhi seluruh kriteria yang telah ditentukan, di mana 6 perusahaan yang menggunakan metode FIFO dan 33 perusahaan yang menggunakan metode rata-rata.

\section{Pengujian Data}

Sebelum pengujian regresi logistik, terlebih dahulu data yang diperoleh akan diuji dengan menggunakan uji analisis statistik deskriptif. Uji analisis statistik deskriptif dilakukan untuk mengetahui nilai maksimum, minimum, rata-rata (mean), dan standar deviasi dari variabel-variabel yang digunakan dalam penelitian ini, disajikan pada Tabel 1 dan 2. 
Tabel 1 Statistik Deskriptif Metode FIFO

\begin{tabular}{lccccc}
\hline & N & Minimum & Maximum & Mean & $\begin{array}{c}\text { Std. } \\
\text { Deviation }\end{array}$ \\
\hline UK (Uk_persh) & 6 & 25.68 & 28.01 & 26.8027 & .84690 \\
IP (Intens_persd) & 6 & 1.99 & 79.52 & 16.1420 & 31.07728 \\
VH (HPP) & 6 & .09 & .47 & .2835 & .13499 \\
VL (Laba_akunt) & 6 & .21 & 1.23 & .7181 & .37330 \\
Valid N (listwise) & 6 & & & & \\
\hline
\end{tabular}

Sumber: Output SPSS Statistik Deskriptif

Rata-rata (mean) yang diperoleh berdasarkan Tabel 1 untuk ukuran perusahaan adalah sebesar 26.802731, sedangkan standar deviasi diperoleh dengan hasil sebesar 0.84690236. Mengacu pada mean dan standar deviasi, maka diperoleh nilai koefisien variasi dari ukuran perusahaan sebesar 0.026643. Hasil ini dihitung dengan menggunakan rumus membagi standar deviasi ukuran perusahaan dengan rata-rata ukuran perusahaan. Hal ini mengindikasikan bahwa semakin besar koefisien varians, maka semakin besar pula perubahan variasi untuk variabel ukuran perusahaan.

Tabel 2 Statistik Deskriptif Metode Rata-rata (Average)

\begin{tabular}{lcrrrr}
\hline & N & Minimum & Maximum & Mean & $\begin{array}{c}\text { Std. } \\
\text { Deviation }\end{array}$ \\
\hline UK (Uk_persh) & 33 & 24.63 & 31.84 & 28.0929 & 1.66672 \\
IP (Intens_persd) & 33 & 1.69 & 18.09 & 6.1083 & 4.01693 \\
VH (HPP) & 33 & .06 & .74 & .2628 & .12798 \\
VL (Laba_akunt) & 33 & .11 & 3.40 & .7957 & .68214 \\
Valid N (listwise) & 33 & & & & \\
\end{tabular}

Sumber: Output SPSS Statistik Deskriptif

Hasil perhitungan dari variabel ukuran perusahaan ditransformasikan menggunakan Ln. Hal ini dilakukan karena nilai dari variabel ukuran perusahaan terlalu besar jika dibandingkan dengan variabel lainnya seperti intensitas persediaan, variabilitas harga pokok penjualan, dan variabilitas laba akuntansi sehingga data perhitungan untuk ukuran perusahaan harus diseragamkan dengan variabel lainnya.

Perusahaan yang menerapkan metode rata-rata (average) mempunyai nilai maksimal yang paling besar untuk ketiga variabel (ukuran perusahaan, variabilitas harga pokok penjualan, dan variabilitas laba akuntansi) dibandingkan perusahaan yang menggunakan metode FIFO. Namun, berbeda halnya pada variabel intensitas persediaan yang memiliki nilai maksimum yang lebih besar pada perusahaan yang menggunakan metode FIFO dibandingkan dengan perusahaan yang menerapkan metode rata-rata (average). Nilai minimum pada variabel ukuran perusahaan dan variabilitas laba akuntansi yang terendah terdapat pada perusahaan yang menggunakan metode rata-rata (average), sedangkan variabel variabilitas harga pokok penjualan dan intensitas persediaan yang terendah terdapat pada perusahaan yang menggunakan metode FIFO. 
Berdasarkan Tabel 1 dan 2, dapat diketahui bahwa standar deviasi terendah untuk kedua variabel, yaitu variabel ukuran perusahaan dan variabilitas laba akuntansi terdapat pada perusahaan yang menggunakan metode FIFO, sedangkan standar deviasi terendah untuk kedua variabel yang lainnya, yaitu variabel intensitas persediaan dan variabilitas harga pokok penjualan terdapat pada perusahaan yang menggunakan metode rata-rata (average).

Hasil perhitungan pada tabel di atas juga menghitung nilai mean (rata-rata) sehingga diketahui bahwa mean dari ukuran perusahaan dan variabilitas laba akuntansi yang menetapkan metode rata-rata (average) lebih besar pada perusahaan yang menerapkan metode FIFO daripada perusahaan yang menerapkan metode rata-rata (average), sedangkan untuk nilai mean (rata-rata) untuk intensitas persediaan atau rasio perputaran persediaan dan variabilitas harga pokok penjualan yang menetapkan metode FIFO lebih besar pada perusahaan yang menerapkan metode rata-rata (average). Mean dari variabilitas laba akuntansi pada metode rata-rata (average) lebih besar daripada mean dari variabilitas laba akuntansi pada metode FIFO. Namun, jika terjadi adanya kenaikan inflasi dari tahun 2005-2009, maka akan menyebabkan nilai mean yang diperoleh dari variabilitas laba akuntansi pada metode FIFO akan menjadi lebih besar daripada mean yang diperoleh dari variabilitas laba akuntansi pada metode rata-rata (average). Hal ini mengindikasikan bahwa perusahaan yang menerapkan metode FIFO pada saat terjadinya inflasi akan menghasilkan laba atau income yang lebih besar dibandingkan dengan perusahaan yang menerapkan metode rata-rata (average). Kekurangan penggunakan metode FIFO saat inflasi, yaitu terlampirnya laba akuntansi yang besar sehingga menyebabkan pajak yang dibayarkan oleh perusahaan menjadi lebih besar. Alasan inilah yang menyebabkan banyak perusahaan lebih memilih untuk menerapkan metode rata-rata (average) pada saat terjadinya inflasi.

Setelah analisis statistik deskriptif, selanjutnya akan dilakukan pengujian secara statistik, yaitu menggunakan uji regresi logistik (logistic regression) untuk mengetahui apakah terdapat pengaruh dari ukuran perusahaan, intensitas persediaan atau rasio perputaran persediaan, variabilitas harga pokok penjualan, dan variabilitas laba akuntansi terhadap pemilihan metode penilaian persediaan, dan membentuk model logistic regression.

Pengujian hipotesis dilakukan dengan menggunakan regresi logistik yang dilakukan secara bersama-sama bagi keempat variabel, yaitu ukuran perusahaan, intensitas persediaan, variabilitas harga pokok penjualan, dan variabilitas laba akuntansi dengan tingkat signifikansi 5\%. Persamaan logistic regression diformulasikan untuk melakukan uji logistic regression Hosmer and Lemeshow Goodness of Fit Test. Berikut ini hasil pengujiannya:

Tabel 3 Pengujian Hosmer and Lemeshow

\begin{tabular}{cccc}
\hline Step & Chi-square & df & Sig. \\
\hline 1 & 10.096 & 8 & .258 \\
\hline \multicolumn{4}{c}{ Sumber: Pengolahan Data SPSS }
\end{tabular}

Berdasarkan hasil pengolahan data di atas, maka telah diperoleh nilai signifikansi Statistics Hosmer and Lemeshow's Goodness of Fit Test sebesar 0.258, yang nilainya di atas 0,05. Hal ini mengindikasikan bahwa tidak terdapat perbedaan yang nyata antara model dengan data. Hal ini juga diartikan bahwa model mampu memprediksi nilai observasinya atau model dapat diterima karena cocok dengan data observasinya. Hal ini berarti model regresi logistik dapat dan layak digunakan untuk analisis selanjutnya. 
Uji regresi logistik yang kedua menggunakan uji -2 log likehood. Uji ini digunakan untuk menilai model regresi logistik layak dipakai atau tidak. Tampilan output SPSS memberikan dua nilai 2 log likehood yaitu untuk model yang yang hanya memasukkan konstanta dan untuk model dengan konstanta dan variabel bebas (independent variable) ke dalam model regresi logistik. Hasil pengolahan data SPSS uji -2 log likehood dapat dilihat pada Tabel 4 dan 5.

Tabel 4 Pengujian -2 log likehood

Block 0: Beginning Block

\begin{tabular}{|c|c|c|c|}
\hline \multicolumn{4}{|c|}{ Iteration History ${ }^{\mathrm{a}, \mathrm{b}, \mathrm{c}}$} \\
\hline \multicolumn{2}{|c|}{ Iteration } & \multirow{2}{*}{$\begin{array}{c}\text {-2 Log likelihood } \\
34.047\end{array}$} & \multirow{2}{*}{$\begin{array}{c}\text { Coefficients } \\
\text { Constant }\end{array}$} \\
\hline Step 0 & 1 & & \\
\hline & 2 & 33.492 & 1.674 \\
\hline & 3 & 33.487 & 1.704 \\
\hline & 4 & 33.487 & 1.705 \\
\hline
\end{tabular}

a. Constant is included in the model.

b. Initial -2 Log Likelihood: 33,487

c. Estimation terminated at iteration number 4 because parameter estimates changed by less than , 001 .

Sumber: Hasil Output SPSS

Block 1: Method = Enter

Tabel 5 Pengujian -2 log likehood

\begin{tabular}{cccc}
\multicolumn{4}{c}{ Model Summary } \\
\hline Step & $\mathbf{- 2}$ Log likelihood & $\begin{array}{c}\text { Cox \& Snell R } \\
\text { Square }\end{array}$ & $\begin{array}{c}\text { Nagelkerke } \mathbf{R} \\
\text { Square }\end{array}$ \\
\hline 1 & $26.433^{\mathrm{a}}$ & .165 & .287 \\
\hline
\end{tabular}

a. Estimation terminated at iteration number 6 because parameter estimates changed by less than, 001 .

Sumber: Hasil Output SPSS

Hasil pengujian -2 log likehood terdiri dari 2 tahap, yaitu tahap 0 dan variabel independen tidak dimasukan ke dalam model regresi dan tahap 1 variabel independen dimasukkan ke dalam model regresi. Hasil yang baik apabila terdapat penurunan pada nilai $-2 \log$ likehood dari tahap 0 ke tahap 1. Hasil -2 log likehood untuk Tabel 4 sebesar 33.487 dan pada Tabel 5 sebesar 26.433. Hal ini berarti terjadi penurunan nilai pada -2 log likehood. Hal ini mengindikasikan bahwa model fit dengan data. Jadi, dapat ditarik kesimpulan bahwa model tersebut merupakan model regresi yang baik dan penambahan variabel bebas (independen) ke dalam model memperbaiki model fit.

Setelah pengujian -2 log likehood selesai, selanjutnya akan diuji dengan uji Nagelkerke's $R$ Square. Uji ini dilakukan untuk menilai seberapa besar variasi dari variabel terikat (metode penilaian persediaan) dapat dijelaskan oleh variabel bebas (ukuran perusahaan, intensitas persediaan, variabilitas 
harga pokok penjualan dan variabilitas laba akuntansi). Dasar pengambilan hasil dalam uji Nagelkerke's $R$ Square dapat dilihat pada nilai Nagelkerke's $R$ Square. Hasil pengujian Nagelkerke's $R$ Square dapat dilihat pada Tabel 6.

Tabel 6 Pengujian Nagelkerke’s R Square

\begin{tabular}{cccc}
\multicolumn{4}{c}{ Model Summary } \\
\hline Step & $-\mathbf{2}$ Log likelihood & $\begin{array}{c}\text { Cox \& Snell R } \\
\text { Square }\end{array}$ & $\begin{array}{c}\text { Nagelkerke R } \\
\text { Square }\end{array}$ \\
\hline 1 & $26.433^{\text {a }}$ & .165 & .287 \\
\hline
\end{tabular}

a. Estimation terminated at iteration number 6 because parameter estimates changed by less than ,001

Sumber: Hasil Output SPSS

Tabel 6 menunjukkan nilai Nagelkerke's $R$ Square adalah sebesar 0.287. Hal ini mengindikasikan bahwa sebesar $28.7 \%$ variasi variabel terikat (metode penilaian persediaan) dapat dijelaskan oleh variabel bebas (ukuran perusahaan, intensitas persediaan atau rasio perputaran persediaan, variabilitas harga pokok penjualan dan variabilitas laba akuntansi), sedangkan sisanya sebesar $71.3 \%$ dijelaskan oleh variabel lain di luar model. Hal ini berarti variabel independen tidak cukup kuat untuk menjelaskan hubungannya dengan variabel dependen.

Pengujian yang dilakukan selanjutnya setelah pengujian Nagelkerke's $R$ Square adalah menggunakan regresi logistik secara parsial dengan melihat tabel variable in the equation. Pengujian hipotesis dengan menggunakan regresi logistik dilakukan dengan memasukkan seluruh variabel ukuran perusahaan, intensitas persediaan, variabilitas harga pokok penjualan, dan variabilitas laba akuntansi pada pemilihan metode penilaian persediaan. Pengujian ini bertujuan untuk melihat pengaruh ukuran perusahaan, intensitas persediaan, variabilitas harga pokok penjualan dan variabilitas laba akuntansi terhadap pemilihan metode penilaian persediaan. Pengujian ini dilakukan dengan menggunakan metode enter dengan tingkat signifikansi sebesar 5\%. Dasar pengambilan keputusannya adalah apabila nilai signifikansi $>0.05$, maka Ha ditolak sedangkan nilai signifikansi $<0.05$, maka Ha diterima. Hasil pengujian adalah sebagai berikut (Tabel 7).

Tabel 7 Pengujian Regresi Logistik (Secara Parsial)

Variables in the Equation

\begin{tabular}{cccccccc}
\hline & & B & S.E. & Wald & df & Sig. & Exp(B) \\
\hline Step $1^{\mathrm{a}}$ & UP & .877 & .501 & 3.066 & 1 & .080 & 2.403 \\
& & & & & & & \\
& IP & -.053 & .038 & 1.934 & 1 & .164 & .949 \\
VH & 2.114 & 4.159 & .258 & 1 & .611 & 8.281 \\
& VL & -.530 & 1.041 & .259 & 1 & .611 & .589 \\
& Constant & -21.934 & 13.661 & 2.578 & 1 & .108 & .000 \\
\hline
\end{tabular}

a. Variable(s) entered on step 1: UP, IP, VH, VL

Sumber: Hasil Output SPSS Binary Logistic 

berikut:

Berdasarkan hasil pengolahan data maka persamaan model logistic regression adalah sebagai

$$
\mathrm{Ln} \frac{\mathrm{MPP}}{1-\mathrm{MPP}}=-21.934+0.877 \mathrm{UK}-0.053 \mathrm{IP}+2.144 \mathrm{VH}-0.530 \mathrm{VL}+\mathrm{e}
$$

Hasil pengujian regresi logistik secara parsial dengan menggunakan metode enter yang dapat dilihat pada Tabel 9 dan dengan melihat nilai signifikansi masing-masing variabel independen. Untuk ukuran perusahaan, nilai signifikansinya sebesar 0.080 dan nilai $0.080>0.05$ berarti Ha ditolak. Ha ditolak mengindikasikan bahwa ukuran perusahaan tidak memiliki pengaruh yang signifikan dalam pemilihan metode penilaian persediaan. Setelah itu dapat dilihat bahwa intensitas persediaan atau rasio perputaran persediaan nilai signifikansinya adalah sebesar 0.164 . Hasil tersebut $>0.05$, maka diartikan bahwa Ha ditolak sehingga dapat disimpulkan bahwa intensitas persediaan tidak memiliki pengaruh yang signifikan dalam pemilihan metode penilaian persediaan.

Variabel independen berikutnya adalah variabilitas harga pokok penjualan. Berdasarkan tabel 4.9 bahwa terlihat nilai signifikansinya sebesar 0.611 dan nilai $0.611>0.05$ dan berarti Ha ditolak. Ha ditolak mengindikasikan bahwa variabilitas harga pokok tidak memiliki pengaruh yang signifikan dalam pemilihan metode penilaian persediaan. Variabel independen yang keempat adalah variabilitas laba akuntansi. Berdasarkan tabel di atas, bahwa terlihat nilai signifikansinya sebesar 0.611 dan nilai $0.611>0.05$ sehingga dapat diambil kesimpulan bahwa Ha ditolak. Hal ini mengindikasikan bahwa variabilitas laba akuntansi tidak memiliki pengaruh yang signifikan terhadap pemilihan metode penilaian persediaan.

Setelah pengujian regresi logistik secara parsial telah dilakukan maka selanjutnya akan dilakukan pengujian regresi logistik secara simultan (bersama-sama). Pengujian dalam regresi logistik ini disebut Omnibus Tests of Model Coefficient. Dalam pengujian ini, semua variabel independen yaitu ukuran perusahaan, intensitas persediaan, variabilitas harga pokok penjualan, dan variabilitas laba akuntansi diuji secara bersama-sama. Omnibus Tests of Model Coefficient bertujuan untuk melihat apakah keempat variabel independen tersebut (ukuran perusahaan, intensitas persediaan, variabilitas harga pokok penjualan, dan variabilitas laba akuntansi) secara bersama-sama berpengaruh dalam pemilihan metode penilaian persediaan. Hasil pengujian Omnibus Tests of Model Coefficient dapat dilihat pada tabel hasil pengolah SPSS (Tabel 8).

Tabel 8 Pengujian Regresi Logistik (Secara Simultan Atau Serentak)

Omnibus Tests of Model Coefficients

\begin{tabular}{llccc}
\hline & & Chi-square & df & Sig. \\
\hline Step 1 & Step & 7.054 & 4 & .133 \\
& Block & 7.054 & 4 & .133 \\
& Model & 7.054 & 4 & .133 \\
\hline
\end{tabular}

Sumber: Hasil Output SPSS Binary Logistic (Omnibus Tests of Model Coefficient)

Tabel 8 merupakan hasil pengujian regresi logistik yang dilakukan secara serentak. Dasar pengambilan keputusan pada pengujian ini adalah dengan melihat nilai signifikansi, di mana tingkat signifikansi (alpha) pada penelitian ini adalah 5\%. Tabel 10 menunjukkan bahwa nilai signifikansi sebesar 0.133 . Nilai signifikansi sebesar $0.133>0.05$, maka dapat disimpulkan bahwa Ha ditolak. Hal ini mengindikasikan bahwa keempat variabel (ukuran perusahaan, intensitas persediaan, variabilitas 
harga pokok penjualan, dan variabilitas laba akuntansi) secara simultan atau bersama-sama tidak berpengaruh secara signifikan terhadap pemilihan metode penilaian persediaan.

Hasil pengujian regresi logistik, baik parsial maupun simultan menyatakan bahwa hasil pengujian nilai signifikansinya berada di atas 0.05 . Hal ini menunjukkan bahwa hasil pengujian regresi logistik, baik secara parsial maupun secara simultan hasilnya konsisten dan sama, yaitu ukuran perusahaan, intensitas persediaan atau rasio perputaran persediaan, variabilitas harga pokok penjualan, dan variabilitas laba akuntansi tidak berpengaruh secara signifikan terhadap pemilihan metode penilaian persediaan.

\section{Hasil Penelitian dan Perbandingan dengan Penelitian Terdahulu} (Tabel 9)

Berdasarkan pengujian yang telah dilakukan, berikut ini adalah ringkasan hasil pengujian Tabel 9 Ringkasan Hasil Pengujian

\begin{tabular}{ll}
\hline \multicolumn{1}{c}{ Variabel } & Hasil Pengujian \\
\hline Ukuran Perusahaan & Tidak Signifikan \\
Intensitas Persediaan & Tidak Signifikan \\
Variabilitas HPP & Tidak Signifikan \\
Variabilitas Laba Akuntansi & Tidak Signifikan \\
Ukuran Perusahaan, Intensitas Persediaan, Variabilitas HPP, dan & Tidak Signifikan \\
Variabilitas Laba Akuntansi & \\
\hline
\end{tabular}

Berdasarkan tabel di atas, dapat dilihat bahwa baik secara parsial maupun simultan, keempat variabel yaitu ukuran perusahaan, intensitas persediaan, variabilitas harga pokok penjualan, dan variabilitas laba akuntansi tidak berpengaruh secara signifikan terhadap pemilihan metode penilaian persediaan. Perbandingan hasil penelitian ini dengan beberapa penelitian terdahulu dapat dijelaskan sebagai berikut. Pada hasil pengujian, untuk ukuran perusahaan menyatakan bahwa ukuran perusahaan tidak berpengaruh secara signifikan terhadap pemilihan metode penilaian persediaan. Hasil penelitian ini konsisten dengan penelitian yang dilakukan oleh Nasser dan Rasita (2005) dan penelitian Anton (2010) yang membuktikan bahwa ukuran perusahaan tidak berpengaruh terhadap pemilihan metode penilaian persediaan. Akan tetapi, penelitian ini tidak konsisten dengan penelitian yang dilakukan oleh Taqwa, Sugiyanto, dan Daljono (2003), Mukhlasin (2002), dan (Logianto dan Murtanto) (2004), yang membuktikan bahwa ukuran perusahaan berpengaruh terhadap pemilihan metode penilaian persediaan.

Hal ini bisa terjadi karena perbedaan waktu yang dilakukan dalam penelitian ini dan terjadinya krisis global Amerika Serikat. Penelitian ini menggunakan periode 2005-2009, di mana juga terjadi kenaikan inflasi dari tahun 2007-2008, yaitu dari 6,6\% menjadi $12.14 \%$. Kenaikan inflasi menyebabkan banyak perusahaan yang pailit dikarenakan terjadinya krisis ini, termasuk perusahaan manufaktur. Secara tidak langsung, dampak krisis Amerika Serikat ini juga berpengaruh terhadap inflasi yang naik di Indonesia. Bagi perusahaan manufaktur, kenaikan inflasi sangat berpengaruh terhadap nilai persediaan, di mana nilai dari persediaan pada saat inflasi mengalami kenaikan. Semestinya kondisi ini memotivasi perusahaan untuk mengambil kebijakan mengganti metode penilaian persediaan agar memperoleh laba yang sesuai dengan kebutuhan perusahaan. Dalam penelitian ini, 33 perusahaan menggunakan metode rata-rata dan 6 perusahaan menggunakan metode FIFO. Dalam kondisi inflasi, metode FIFO akan menyajikan laba yang lebih tinggi. Pada tahun 2008, pasar saham dunia terpuruk. Perubahan metode penilaian persediaan dari metode rata-rata ke FIFO akan menyebabkan laba perusahaan menjadi lebih tinggi dan diharapkan saham perusahaan dapat terjual dengan harga yang menguntungkan perusahaan. Namun, penelitian ini menunjukkan bahwa ukuran perusahaan tidak berpengaruh terhadap pemilihan metode penilaian persediaan karena 
perusahaan yang digunakan dalam penelitian ini adalah perusahaan yang terdaftar di BEI; dengan kata lain, perusahaan yang digunakan dalam penelitian ini adalah tergolong perusahaan besar. Perusahaan besar memiliki kecenderungan untuk menggunakan metode rata-rata agar laba perusahaan terlihat tidak setinggi jika menggunakan metode FIFO sehingga pajak yang dibayarkan juga rendah. Hal inilah yang menguatkan bahwa metode average banyak digunakan oleh perusahaan manufaktur yang ada di Indonesia. Di samping itu, total aset tidak hanya dipengaruhi oleh saldo persediaan saja yang tergantung pada metode penilaian persediaan yang digunakan, tetapi juga dipengaruhi oleh saldo lain seperti kas, piutang dagang, peralatan, dan akun-akun lain yang masuk dalam total aset sehingga ukuran perusahaan yang diukur dengan total aset tidak berpengaruh terhadap pemilihan metode penilaian persediaan.

Hasil pengujian untuk intensitas persediaan menyatakan bahwa intensitas persediaan atau rasio perputaran persediaan tidak berpengaruh secara signifikan terhadap pemilihan metode penilaian persediaan. Perusahaan yang menggunakan metode rata-rata memiliki indikasi inventory turnover yang tinggi, sebaliknya perusahaan yang menggunakan metode FIFO mempunyai indikasi inventory turnover yang rendah. Berdasarkan hasil tersebut, dapat diketahui hasil penelitian ini konsisten dengan penelitian yang dilakukan oleh Logianto dan Murtanto (2004) dan Nasser dan Rasita (2005), yang membuktikan bahwa intensitas persediaan tidak berpengaruh terhadap pemilihan metode penilaian persediaan. Akan tetapi, penelitian ini tidak konsisten dengan penelitian yang dilakukan oleh Mukhlasin (2002), yang membuktikan bahwa intensitas persediaan atau rasio perputaran persediaan berpengaruh terhadap pemilihan metode penilaian persediaan. Hal ini dikarenakan pada penelitian ini perusahaan yang menggunakan metode rata-rata ada yang memiliki persediaan akhir yang tinggi sehingga memiliki inventory turnover yang rendah. Hal ini yang menyebabkan perusahaan yang menggunakan metode rata-rata (average) sebagian memiliki indikasi inventory turnover yang tinggi dan sebagian lagi memiliki inventory turnover yang rendah, sebagaimana jika perusahaan yang menggunakan metode FIFO.

Hasil pengujian untuk variabilitas harga pokok penjualan menyatakan bahwa variabilitas harga pokok penjualan tidak berpengaruh secara signifikan terhadap pemilihan metode penilaian persediaan. Berdasarkan hasil tersebut, dapat diketahui bahwa hasil penelitian ini konsisten dengan penelitian yang dilakukan oleh Logianto dan Murtanto (2004) dan Nasser dan Rasita (2005), yang membuktikan bahwa variabilitas harga pokok penjualan tidak berpengaruh terhadap pemilihan metode penilaian persediaan. Akan tetapi, penelitian ini tidak konsisten dengan penelitian yang dilakukan oleh Mukhlasin (2002), yang membuktikan bahwa variabilitas harga pokok penjualan berpengaruh terhadap pemilihan metode penilaian persediaan. Hal ini mungkin dikarenakan terjadinya inflasi pada penelitian ini, yaitu di tahun 2007-2008. Kondisi inflasi (perubahan harga), selain berpengaruh terhadap persediaan akhir, juga dapat berpengaruh terhadap harga pokok penjualan, di mana dengan adanya kenaikan tingkat inflasi, harga pokok penjualan akan mengalami kenaikan sehingga dapat mempengaruhi nilai pada harga pokok penjualan di laporan keuangan, yang juga akan mempengaruhi laba yang akan diperoleh oleh perusahaan. Secara umum, perusahaan ternyata mengharapkan laba yang rendah karena pajaknya juga rendah sehingga ketika inflasi perusahaan akan tetap menggunakan metode rata-rata yang menunjukkan harga pokok penjualan yang tinggi dengan laba yang rendah, dibandingkan jika menggunakan metode FIFO.

Hasil pengujian terakhir yaitu pengujian pada variabilitas laba akuntansi menyatakan bahwa variabilitas laba akuntansi tidak berpengaruh secara signifikan terhadap pemilihan metode penilaian persediaan. Berdasarkan hasil tersebut, dapat diketahui bahwa hasil penelitian ini konsisten dengan penelitian yang dilakukan oleh Nasser dan Rasita (2005) dan Anton (2010), yang membuktikan bahwa variabilitas laba akuntansi tidak berpengaruh terhadap pemilihan metode penilaian persediaan. Akan tetapi, penelitian ini tidak konsisten dengan penelitian yang dilakukan oleh Mukhlasin (2002) dan Logianto dan Murtanto (2004), yang membuktikan bahwa variabilitas laba akuntansi berpengaruh terhadap pemilihan metode penilaian persediaan. 


\section{SIMPULAN}

Tujuan penelitian ini adalah untuk melihat apakah terdapat pengaruh yang signifikan antara ukuran perusahaan, intensitas persediaan, variabilitas harga pokok penjualan, dan variabilitas laba akuntansi terhadap pemilihan metode penilaian persediaan pada perusahaan manufaktur yang terdaftar di Bursa Efek Indonesia pada tahun 2005-2009. Jumlah sampel yang diambil dalam penelitian ini adalah sebanyak 39 perusahaan, di mana selama periode penelitian 6 perusahaan menggunakan metode FIFO, sedangkan 33 perusahaan menggunakan metode rata-rata. Pengambilan sampel menggunakan purposive sampling dengan kriteria yang telah ditetapkan sebelumnya. Berdasarkan hasil pengujian, kesimpulan yang dapat diambil adalah baik secara parsial maupun simultan variabel ukuran perusahaan, intensitas persediaan, variabilitas harga pokok penjualan, dan variabilitas laba akuntansi perusahaan tidak berpengaruh signifikan terhadap pemilihan metode penilaian persediaan.

Hasil penelitian ini ada yang konsisten dan juga ada yang tidak konsisten dengan peneliti terdahulu. Hasil penelitian yang berbeda mungkin disebabkan karena adanya perbedaan waktu periode penelitian dan terjadinya inflasi, yang banyak mengakibatkan perusahaan menjadi pailit. Penelitian ini memiliki keterbatasan sebagai berikut (1) Perusahaan manufaktur yang digunakan sebagai sampel pada penelitian ini bukan pada industri yang sejenis (contoh: hanya industri makanan saja), di mana setiap jenis industri atau perusahaan manufaktur memiliki penilaian yang berbeda terhadap persediaannya sehingga akan menunjukkan hasil yang berbeda; (2) Variabel penelitian yang digunakan hanya 4 variabel, yaitu ukuran perusahaan, intensitas persediaan, variabilitas harga pokok penjualan, dan variabilitas laba akuntansi.

Seperti telah diuraikan sebelumnya, penelitian ini mengandung keterbatasan-keterbatasan. Namun, hasil penelitian setidaknya dapat memotivasi dilakukannya penelitian berikutnya. Dengan mempertimbangkan keterbatasan-keterbatasan yang ada, diharapkan penelitian-penelitian yang akan datang memperbaiki faktor-faktor (1) Sampel penelitian sebaiknya menggunakan jenis industri yang sejenis, agar lebih dapat menunjukkan pengaruh yang sesungguhnya terhadap metode penilaian persediaan pada setiap jenis industri; (2) Menggunakan respoden selain perusahaan manufaktur seperti perusahaan perdagangan; (3) Sebaiknya memperpanjang periode penelitian agar lebih dapat menjelaskan variabilitas data yang sesungguhnya; (4) Memperbanyak variabel penelitian seperti variabilitas persediaan, financial leverage, intensitas modal, dan rasio lancar.

\section{DAFTAR PUSTAKA}

Abdullah, S., dan Muslim A.D. (Agustus, 2004). Apakah metode FIFO dan rata-rata memang berbeda: Bukti empiris dari Bursa Efek Jakarta. Metode Riset Akuntansi, Auditing dan Informasi, 4(2), 151- 172 .

Anton. (2010). Evaluasi Pengaruh Variabilitas Persediaan, Variabilitas Laba Akuntansi, dan Ukuran Perusahaan terhadap Pemilihan Metode Akuntansi Persediaan pada Perusahaan Manufaktur yang Terdaftar di BEI pada periode 2005-2008. Tesis S1 Tidak Dipublikasikan, Jakarta: Universitas Tarumanagara.

Baridwan, Z. (2000). Intermediate accounting, Jakarta: Erlangga.

Ikatan Akuntan Indonesia. (2009). Standar akuntansi keuangan, Jakarta: Salemba Empat. 
Kieso, D.E., Weygant, J.J., dan Terry, D.W. (2007). Intermediate accounting, $12^{\text {th }}$ ed., Danvers: Wiley.

Lee, C.J., and Hsieh, D.A. (1985). Choice of inventory accounting methods: Comparative analysis of alternative hypothesis, Journal of Accounting Research, Autumn, pp: 468-485.

Logianto, S., dan Murtanto. (2004). Analisis metode akuntansi persediaan terhadap price earning ratio. Jurnal Bisnis dan Akuntansi, 6(2), 189-207.

Mukhlasin. (2002). Analisis pemilihan metode akuntansi persediaan berdasarkan richardian hipotesis. Jurnal Ekonomi dan Bisnis Fakultas Universitas Katolik Indonesia Atmajaya, Februari, 21-39.

Nasser, E.M, dan Rasita, E. (2005). Pemilihan metode akuntansi persediaan berdasarkan richardian hipotesis, teory agency, dan politicial cost serta pengaruhnya terhadap PER. Jurnal Ekonomi STEI, 4(31), 19-41.

Niehaus, G.T. (1989). Ownership structure and inventory method choice, Accounting Review, 64 (April), 269-284.

Taqwa, S., Sugiyanto, F.X., dan Daljono. (2003). faktor-faktor yang mempengaruhi pemilihan metode akuntansi persediaan pada perusahaan manufaktur di BEJ. Jurnal Riset Akuntansi Indonesia, $2,100-118$.

Tuanakotta, T.M. (2000). Teori akuntansi, buku kedua, Jakarta: Lembaga Penerbit Fakultas Ekonomi Indonesia.

Watts, R.L., dan Zimmerman, J.L. (1986). Positive accounting theory, Prentice-Hall International Edition.

Wolk, H.I., dan Tearney, M.G. (1977). Accounting theory, $4^{\text {th }}$ ed., Southwestern College Publishing. 